\title{
Involvement of Mobile phones as a source for Nosocomial infections
}

\author{
Priyanka Shukla1, Bushra Khalid², Shadma Yaqoob ${ }^{3}$, Sharique Ahmad ${ }^{4}$ \\ ${ }^{1}$ Associate Professor, ${ }^{3}$ Professor, Department of Microbiology, Era's Lucknow Medical College and Hospital, Era \\ University, Lucknow -226003, U.P, India, 'Intern, Era's Lucknow Medical College and Hospital, Era University, Lucknow \\ -226003, U.P, India, 'Professor, Department of Pathology, Era's Lucknow Medical College and Hospital, Era University, \\ Lucknow -226003, U.P, India
}

Background: Mobile phones are communication devices for communication nowadays and have emerged as a need of our life. Mobile phones also act as a reservoir for microorganisms. Human skin, wallets, bags, environment and food items are major sources of contamination for mobile phones. Medical students, healthcare workers and other non-teaching staff nowadays use mobile phones for communication in the workplace. Mobile phone contamination spreads from surfaces to hands. Aims and Objective: Our study was aimed to investigate the contamination of mobile phones by pathogens among health care workers. The objective of this study was to document for the role of mobile phones as sources in nosocomial infections. Materials and Methods: The study was done in Department of Microbiology and Pathology, Era's Lucknow Medical College and Hospital, including teaching staffs from hospital and college, health care workers in all laboratories and wards. A total of 200 swab samples from various mobile phones of medical and technical staff of various wards, Outpatient Department Treatment, laboratories was collected after taking informed written consent from them. Culture was done on Blood Agar, MacConkey Agar, and Sabouraud's dextrose agar. After overnight incubation, colonies were identified by Gram's stain and Biochemical tests. Results: Highest mobile phone users are medical students, residents followed by teaching faculty. Smart phones or touch screen mobiles were used by maximum ie.90.5\%. Among the isolated bacteria, Bacillus (39.5\%), CONS (19\%), E.coli (15.5\%), Klebsiella (10.5\%), Pseudomonas (5.5\%), Staphylococcus aureus (4\%), Enterococcus (2.5\%). No growth was seen in $3.5 \%$ mobile phone sample cultures. Not a single fungal pathogen was isolated. Conclusion: The findings is the present study suggests that the mobile phones used by medical staff and health care workers act as source of transmission vehicles for pathogenic microorganisms.

\section{Access this article online}

Website:

http://nepjol.info/index.php/AJMS DOI: $10.3126 / a j m s . v 12 i 7.34788$

E-ISSN: 2091-0576

P-ISSN: $2467-9100$

Copyright (c) 2021 Asian Journal of Medical Sciences

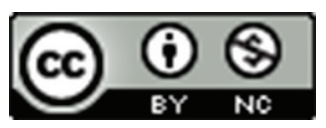

This work is licensed under a Creative Commons Attribution-NonCommercial 4.0 International License.

\section{INTRODUCTION}

Mobile phones are communication devices for communication nowadays and have emerged as a need of our life. It can be a vector for microbial transmission. As it comes to direct contact with human body, microorganisms transfer from body to environment. ${ }^{1}$ Mobile phones also act as a reservoir for microorganisms. Human skin, wallets, bags, environment and food items are major sources of contamination for mobile phones. These are vehicles by which microorganisms contaminate phone, causing various infections. ${ }^{2}$ Medical students, healthcare workers and other non-teaching staff use mobile phones for communication at the workplace. Mobile phone contamination also spreads from surfaces to hands. ${ }^{3}$ According to a study $>90 \%$ of mobile phones of health-care workers were found contaminated with microorganisms and $>14 \%$ of them were found contaminated with pathogenic bacteria causing nosocomial infections. ${ }^{4}$ Microorganisms isolated are normal flora, can also serve as reservoirs for infections, allowing the spread of bacteria to hospital environment. Sharing of mobile phones among the population may also facilitates the spread of pathogenic bacteria in to the community. Mobile phones can get contaminated by bacteria (such as Escherichia coli, Psendomonas 
aeruginosa and Klebsiella pneumoniae), which also cause hospital infections, and serve as a vehicle for the spread of nosocomial infections. Coagulase negative Staphylococcus, followed by Staphylococcus aureus, E.coli, and Enterococcus fecalis, followed by Klebsiella pneumonia, Bacillus spp. and P.aeruginosa. ${ }^{5-10}$ Mobile phones are potential threats for hospital infection control and may increase rate of hospital acquired infections. ${ }^{11}$ Mobile phones are seldom cleaned and touched many times during or after the examination of patients without washing hands, can transmit various pathogens and play a potential vehicle of nosocomial infections for hospitalized patients. Nosocomial infections are a threat in all hospitals. ${ }^{12}$ Mobile phones spread microorganisms because bacteria multiply at a raised temperature and mobile phones are sites of multiplication for microbes as they are in a warm environment in pockets and handbags. The constant handling of mobile phones and the heat generated by the mobile phones creates an ideal multiplication site for microorganisms that are present as normal flora on skin. ${ }^{13,14}$ The objective of this study was to find evidence for the potential role of mobile phones as sources in nosocomial infections. Our study had aim to investigate the contamination of mobile phones by pathogens among health care workers.

\section{Materials and methods}

The study was conducted in Department of Microbiology and Pathology, Era Lucknow Medical College and Hospital, Lucknow. In this study teaching staffs from hospital and college, health care workers in all laboratories and wards. A total of 200 swab specimens from mobile phones of health care workers from various wards, Outpatient Department Treatment, laboratories was collected after taking informed written consent from them.

\section{MATERIALS AND METHODS}

Two sterile cotton swabs were taken, one for bacterial culture and other for fungal culture. Swab used for bacterial culture was moistened with peptone water. Swabs were rubbed on keyboard screen, front, back and sides of mobile phones as these zones are most frequently in contact with fingers. Mobile phones having cover, swabs were rubbed on outer surface of cover also. If someone owned two mobile phones, separate sets of swabs were used for sample collection. After collection of samples, immediate transportation was done to lab. Informed written consent was taken from each healthcare worker. Alcohol based sanitizer was used to sanitize before sample collection from mobile phones before swabbing mobile phone. Collected samples were labeled with specific code, date, name, age, sex and address. One swab was used for plating blood agar, nutrient agar, MacConkey agar and the other swab was used for culture on SDA; overnight incubation was done at $37^{\circ} \mathrm{C}$ for $18-24$ hours in case of bacterial isolation.
In case of fungal isolation swab was gently rubbed on slant of culture bottle containing SDA with Actidione and kept in Biological oxygen Demand incubator at $25^{\circ} \mathrm{C}$ for at least 3 weeks SDA culture bottles showing no growth up to 3 weeks were discarded and reported as negative. Plates were labeled with specific code and number.

In case of bacterial isolates, plates showing no growth were reported. Culture plates showing visible growth from each plate was identified by Gram's staining and biochemical testing for respective bacteria. In case of fungal isolates, visible growth was identified by slide culture and Lacto Phenol Cotton Blue mount.

\section{Exclusion criteria \\ Lack of mobile phones.}

Inclusion criteria

All medical and non-medical staff having mobile phones.

\section{RESULTS}

The study was done in Era Lucknow Medical College and Hospital. About 200 persons including students, residents, teaching and non-teaching staff, paramedical staff, lab technicians were included in our study after obtaining informed written consent from them.

In this study it is evident that the maximum mobile phone usage of mobile phones is by medical students and residents followed by teaching faculty. Apart from this laboratory technicians and non-teaching staff were also there (Table 1). The use of mobile phone has increased much because people use their mobiles for social networking, games and literature search.

According to this table-only 9.5\%people had normal keyboard phones. Smart phones or touch screen mobiles were used by maximum ie.90.5\% (Table 2).

Mobile phones are a common source of contamination. Mobile phones with flap or cover are a possible source of contamination. Here in this study $66.5 \%$ contamination was found in mobiles with cover where as $31.5 \%$ phones were without cover (Table 3).

\begin{tabular}{lc} 
Table 1: Mobile user group \\
\hline Mobile user group & $\mathbf{N = \% ( 2 0 0 )}$ \\
\hline Students & $58(29 \%)$ \\
Residents & $29(14.5 \%)$ \\
Teaching staff & $32(16 \%)$ \\
Non-teaching staff & $31(15.5 \%)$ \\
Laboratory technicians & $20(10 \%)$ \\
Nursing staff & $30(15 \%)$ \\
\hline
\end{tabular}


Regular decontamination of mobile phones was seen in only $24.5 \%$ subjects. Remaining $75.5 \%$ person were not habituated to clean their phones (Table 4).

Among the isolated bacteria Bacillus (39.5\%), Coagulase Negative Staphylococcus (19\%), E.coli (15.5\%), Klebsiella (10.5\%), Pseudomonas (5.5\%), Staphylococcus aureus (4\%), Enterococcus (2.5\%). No growth was seen in 3.5\% mobile phone sample cultures. Not a single fungal pathogen was isolated.

\section{DISCUSSION}

Medical staff and Health care workers present in health-care settings use mobile phone as communication device. Mobile phones act as vehicles for transmission of infection to patients. Mobile phone contamination in hospital by bacteria is increased rapidly because these devices act as a reservoir as well as source of bacterial contamination specially in the operation theaters, intensive care units and surgical wards etc. ${ }^{15}$ Patient safety is also affected as the bio-transfer potential of the mobile phones, especially in case of susceptible patients. ${ }^{16}$ It is suggested that medical staff and health care workers should be trained at frequent intervals during training programs for patient safety, to increase their awareness and knowledge about infection transmission by mobile phones, prevention, and control in hospital environments.

Most of the mobile phones involved in our study had never been cleaned. This is lesser than in previous studies, which showed that $80-92 \%$ of staff had never decontaminated

Table 2: Type of phone used
\begin{tabular}{lc}
\hline Type of phone & $\mathbf{N}=\%$ \\
\hline Normal & $19(9.5 \%)$ \\
Smart phone & $181(90.5 \%)$ \\
\hline
\end{tabular}

\begin{tabular}{lc} 
Table 3: Covered and Uncovered phone \\
\hline Texture of phone & $\mathbf{N}=\%$ \\
\hline Phone with cover & $137(66.5 \%)$ \\
Uncovered phone & $63(31.5 \%)$ \\
\hline
\end{tabular}

\begin{tabular}{ll} 
Table 4: Cleaning of phone \\
\hline Yes & $49(24.5 \%)$ \\
No & $151(75.5 \%)$ \\
\hline
\end{tabular}

\begin{tabular}{lc} 
Table 5: Pathogens isolated from mobile phone \\
\hline Staphylococcus aureus & $8(4 \%)$ \\
CONS & $38(19 \%)$ \\
E. coli & $31(15.5 \%)$ \\
Klebsiella & $21(10.5 \%)$ \\
Pseudomonas & $11(5.5 \%)$ \\
Bacillus & $79(39.5 \%)$ \\
Enterococcus & $5(2.5 \%)$ \\
No Growth & $7(3.5 \%)$ \\
\hline
\end{tabular}

their mobile phones. One of the most commonly used methods of cleaning of mobile phones is cleaning the phone with $70 \%$ alcohol by which there is reduction in the number of bacterial counts. ${ }^{17-20}$

Education and training of medical staff and health care workers can be a part of training programs in hospital infection control, which helps in increasing awareness of transmission of pathogenic microorganisms from healthy individuals to susceptible patients. Hand hygiene awareness is a basic infection control measures. ${ }^{21,22}$

The type of mobile phone i.e. smart phone or normal keypad phone used also increases the chance of contamination by bacteria and spread of pathogens in community. In case of key pad, the rubber pads help the microorganism to adhere to the surface of the keypads and contaminate it acting as a source of microbial infection. The touch screen of smart phones helps in exchange of microbial flora from hands to screen mobile phone and from mobile phone to person using it. Mobile phone covers are also ideal site for microorganism to multiply. These covers protect the microorganisms and provide an ideal environment to grow and multiply. De contamination method of mobile phone varies from person to person depending on their knowledge of usage, attitude and awareness. Many people have a habit of cleaning their phones by rubbing it on their clothes. Some people may use handkerchief or tissue paper to clean mobile phones. From this study, we came to know that the study subjects were not having awareness about the contamination in their mobile phones. Most of them do not know the methods of keeping their mobile phones clean.

\section{CONCLUSION}

Mobile phones are the most commonly used communication devices in the community and healthcare settings nowadays. Our findings suggest that the mobile phones used by medical staff and health care workers act as source of transmission vehicles for pathogenic microorganisms. Regular training programs should be conducted in medical colleges on guidelines of restricted use of mobile phones in hospitals and increasing awareness of hand hygiene. Frequent and regular hand washing is the only factor which can reduce the risk of bacterial contamination of mobile phones. Also, decontamination or regular cleaning of mobile phones with alcohol rub, wet disinfectant wipes or with $70 \%$ isopropyl alcohol can be effective in cleaning of mobile phones.

\section{ACKNOWLEDGEMENT}

The authors take this opportunity to thank Department of Microbiology and Pathology, Era's Lucknow Medical 
College and Hospital, Era University, India to carry out the present study.

\section{REFERENCES}

1. Nowakowicz-Dębek B, Łukasz W, Henryk K, Halina P and Beata T. Reduction of microbial contamination of mobile phones using ultraviolet UV radiation and ozone. African Journal of Microbiology Research. 2014; 7: 5541-5545.

https://doi.org/10.5897/AJMR2013.6142

2. Shahaby AF, Awad NS, El-Tarras AE and Bahobial S. Mobile phone as potential reservoirs of bacterial pathogens. African Journal of Biotechnology. 2012; 11: 15896-15904.

https://doi.org/10.5897/AJB12.1836

3. Reynolds K, Pamela W, Stephanie B and Charles G. Occurrence of bacteria and biochemical markers on public surfaces. International journal of environmental health research. 2005; 15: 225-234.

https://doi.org/10.1080/09603120500115298

4. Brady R, Wasson A, Stirling I, McAllister C and Damani NN. Is your phone bugged? The incidence of bacteria known to cause nosocomial infection on healthcare workers' mobile phones. The Journal of hospital infection. 2006; 62: 123-125.

https://doi.org/10.1016/j.jhin.2005.05.005

5. Mohammadi SM and Karbasizadeh V. Bacterial contamination of healthcare workers' mobile phones and efficacy of surface decolonization techniques. African Journal of Microbiology Research. 2011; 5(30): 5415-5418.

https://doi.org/10.5897/AJMR11.1062

6. Ulger F, Esen S, Dilek A, Yanik K, Gunaydin M and Leblebicioglu $\mathrm{H}$. Are we aware how contaminated our mobile phones with nosocomial pathogens?. Annals of clinical microbiology and antimicrobials. 2009; 8: 7 .

https://doi.org/10.1186/1476-0711-8-7

7. Ettelt S, Nolte E, Mckee M, Haugen O, Karlberg I, Klazinga N, et al. Evidence-based policy? The use of mobile phones in hospital. Journal of public health. 2006; 28(4): 299-303.

https://doi.org/10.1093/pubmed/fdl067

8. Brady R, Fraser SF, Dunlop MG, Paterson-Brown S and Gibb AP. Bacterial contamination of mobile communication devices in the operative environment. The Journal of hospital infection. 2007; 66: 397-398.

https://doi.org/10.1016/j.jhin.2007.04.015

9. Ulger F, Dilek A, Esen S and Sumbal M. Are Healthcare worker's mobile phones a potential source of nosocomial infections. J Infect Ctries. 2015; 9(10): 1046-1053.

https://doi.org/10.3855/jidc.6104

10. Borer A, Gilad J, Smolyakov R, Eskira S, Peled N and Porat N. Cell phones and Acinetobacter transmission. Emerg Infect Dis. 2005; 11: 1160-1161. https://doi.org/10.3201/eid1107.050221

11. Brady RR, Verran J, Damani NN and Gibb AP. Review of mobile commu-nication devices as potential reservoirs of nosocomial pathogens. J Hosp Infect. 2009; 71: 295-300.

https://doi.org/10.1016/j.jhin.2008.12.009

12. Goldblatt JG, Krief I, Klonsky T, Haller D, Milloul V, Sixsmith DM, et al. Use of cellular telephones and transmission of pathogens bymedical staff in New York and Israel. Infect Control Hosp Epidemiol. 2007; 28: 500-503.

https://doi.org/10.1086/513446

13. Braddy $\mathrm{CM}$ and Blair JE. Colonization of personal digital assistants used in a health care setting. Am J Infect Control. 2005; 33(4): 230-232.

https://doi.org/10.1016/j.ajic.2005.03.003

14. Singh D, Kaur H, Gardner WG and Treen LB. Bacterial contamination of hospital pagers. Infect Control Hosp Epidemiol. 2002; 23: 274-276.

https://doi.org/10.1086/502048

15. Hassoun A, Vellozzi EM and Smith MA. Colonization of personal digital assistants carried by healthcare professionals. Infect Control Hosp Epidemiol. 2004; 25(11): 1000-1001.

https://doi.org/10.1086/502334

16. Akinyemi KO, Atapu $\mathrm{AD}$, Adetona $\mathrm{OO}$ and Coker $\mathrm{AO}$. The potential role of mobile phones in the spread of bacterial infections. J Infect Dev Ctries. 2009; 3(8): 628-632.

https://doi.org/10.3855/jidc.556

17. Namias N, Widrich J, Martinez OV and Cohn SM. Pathogenic bacteria on personal pagers. Am J Infect Control. 2000; 28: 387-988. https://doi.org/10.1067/mic.2000.109183

18. Julian T, Singh A, Rousseau J and Weese JS. Methicillin-resistant staphylococcal contamination of cellular phones of personnel in a veterinary teaching hospital. BMC Res Notes. 2012; 5: 193. https://doi.org/10.1186/1756-0500-5-193

19. Anuradha, Kumar A, Mekhanayakee, Shyen WY and Arwintharao. Study on awareness of microbial contamination through mobile phones. Asian pacific journal of health sciences. 2016; 3(4): 313-323. https://doi.org/10.21276/apjhs.2016.3.4.50

20. Akinyemi KO, Atapu $A D$, Adetona $O O$ and Coker AO. The potential role of mobile phones in the spread of bacterial infections. J Infect Dev Ctries. 2009; 3: 628-632. https://doi.org/10.3855/jidc.556

21. Namias N, Widrich J, Martinez OV and Cohn SM. Pathogenic bacteria on personal pagers. Am J Infect Control. 2000; 28: 387-388. https://doi.org/10.1067/mic.2000.109183

22. Ulian T, Singh A, Rousseau J and Weese JS. Methicillin-resistant staphylo-coccal contamination of cellular phones of personnel in a veterinary teaching hospital. BMC Res Notes. 2012; 5: 193. https://doi.org/10.1186/1756-0500-5-193

\footnotetext{
Author's contributions:

PS-Concept and design of the study, interpreted the results, prepared first draft of manuscript and critical revision of the manuscript; BK- Design of the study, Sample collection and coordination of the overall study; SY- Statistically analyzed and interpreted, reviewed the literature and manuscript preparation; SADrafting and Preparation of manuscript, revision of the manuscript

Work attributed to:

Department of Microbiology and Pathology, Era's Lucknow Medical College and Hospital, Era University, India.

Orcid ID:

Dr Priyanka Shukla- (1) https://orcid.org/0000-0002-7903-8778

Ms Bushra Khalid- (i) https://orcid.org/0000-0002-2272-9375

Dr Shadma Yaqoob- io https://orcid.org/0000-0002-9267-4867

Dr Sharique Ahmad- ohttps://orcid.org/0000-0002-9637-8838

Sources of Funding: None, Conflict of Interest: None.
} 